\title{
The enzymology of dicarboxylic acid formation by Corynebacterium sp. strain 7E1C grown on n-alkanes
}

\author{
Neil M. Broadway $\dagger$ F. Mark Dickinson and Colin Ratledge* \\ Department of Applied Biology, University of Hull, Cottingham Road, Hull HU6 7RX, UK
}

(Received 18 September 1992; revised 25 January 1993; accepted 12 February 1993)

\begin{abstract}
Cultures of the Gram-positive bacterium Corynebacterium sp. strain 7E1C contained up to $300 \mathrm{mg}$ dodecanedioic acid $\mathrm{l}^{-1}$ after growth on dodecane. Small amounts of tetradecanedioic acid (17 to $45 \mathrm{mg} \mathrm{l}^{-1}$ ) were produced during growth on tetradecane or methyl tetradecanoate. No dicarboxylic acids were detected after growth on hexadecane, hexadecanoic acid or 16-hydroxyhexadecanoic acid. Studies on the rates of degradation of exogenous dicarboxylic acids showed that this is not a significant factor influencing the accumulation of dodecanedioic and tetradecanedioic acids. The activities and substrate specificities of a number of enzyme activities involved in dicarboxylic acid metabolism were investigated. The specificities of the long-chain acyl-CoA synthetase and thioesterase, alcohol dehydrogenases and $\beta$-oxidation are consistent with the accumulation of dodecanedioic acid from dodecane and the lack of production of hexadecanedioic acid from hexadecane. The $\omega$-hydroxy fatty acid may occupy a pivotal position in determining whether significant production of dicarboxylic acid occurs with this organism.
\end{abstract}

\section{Introduction}

Certain yeasts and bacteria produce long-chain dicarboxylic acids from alkanes, n-alkanols and fatty acids both during growth on these substrates and from resting cells presented with these substrates (Bacchin et al., 1974; Kester \& Foster, 1963; Shiio \& Uchio, 1971; Uchio \& Shiio, 1972 $a, b c$; Yi \& Rehm 1982a, $b, c$, $1988 a, b)$. There has been much industrial interest in microbial dicarboxylic acid production (e.g. Casey \& Macrae, 1992; Casey et al., 1990) and numerous dicarboxylic-acid-producing microbes have been patented (see Buhler \& Schindler, 1984).

To date, most of the commercial work on microbial dicarboxylic acid metabolism has concentrated on random mutagenesis to produce mutants giving increased dicarboxylic acid yields (Hill et al., 1986; Casey et al., 1990; Furukawa et al., 1986). These mutants are presumably blocked in $\beta$-oxidation. Other physiological studies have aimed at optimizing either culture condi-

*Author for correspondence. Tel. (0482) 465243; fax (0482) 465458.

$\dagger$ Present address: Department of Biochemistry and Molecular Biology, University College London, London WC1E 6BT, UK.

Abbreviations: $\mathrm{DC}_{n}$, dicarboxylic acid with a chain-length of $n$ carbon atoms; DTNB, 5,5'-dithiobis(2-nitrobenzoic acid); DMSO, dimethylsulphoxide; PMS, phenazine methosulphate; DCPIP, 2,6dichlorophenolindophenol. tions (e.g. Uchio \& Shiio, $1972 a$ ) or the condition of the cells to which the alkane is presented (Chan et al., 1991). Working entirely with whole cells, Yi \& Rehm $(1982 a, b, c)$ demonstrated that dicarboxylic acids can be formed from alkanes via both the $\alpha, \omega$-diol and fatty acid routes (see Fig. 3). In Candida tropicalis, the fatty acid route is the major pathway (Yi \& Rehm, 1982c).

Despite the enzymology of monoterminal alkane oxidation (i.e. alkane to fatty acid) having been investigated in considerable detail (for reviews see Boulton \& Ratledge, 1984; Buhler \& Schindler, 1984; Rehm \& Reiff, 1981), there has been little published on the enzymology of dicarboxylic acid metabolism. Modrzakowski \& Finnerty (1989) reported the induction of a dicarboxyl-CoA synthetase in Acinetobacter sp. HO1-N grown on one of four alkyl ethers, which were degraded via the corresponding dicarboxylic acid. Activation of a range of dicarboxylic acids from malonate to sebacate was examined and, as these activities varied according to the chain-length of the diethyl growth substrate, it could be that more than one acyl-CoA synthetase was being expressed in the organism. Growth of the bacterium on hexadecane was less effective in inducing activity of the diacyl-CoA synthethase. Yi \& Rehm (1988a) examined the degradation of 1,18-octadec-9-enoic acid (formed from oleic acid) by whole cells of $C$. tropicalis and observed the formation of a series of unsaturated dicarboxylic acids down to hexenedioic acid that were presumed to arise by direct $\beta$-oxidation. 
There have been two studies in which investigations of dicarboxylic acid production by whole cells have been accompanied by enzymological studies. Blasig et al. (1988) found that when membrane preparations of the yeast Candida maltosa (formerly Lodderomyces elongisporus) were incubated with hexadecane the diterminal oxidation product, hexadecanedioic acid, was a minor $(10 \%)$ oxidation product and monoterminal attack predominated. This correlated well with whole cell studies (Blasig et al. 1984). Zhihua \& Xiuzhen (1986) reported, somewhat surprisingly, a higher activity of dodecanedioyl-CoA synthase in acetate-grown cells of Candida tropicalis than in cells grown on long-chain alkanes. A single, broad-specificity acyl-CoA synthetase may be indicated here, as acetyl-CoA synthetase was similarly induced in cells grown on alkanes or acetate. Mutants of this yeast have been produced showing increased accumulation of hexadecanedioic acid (Yuantong \& Xiuzhen, 1988).

In the present work, we have investigated the enzymology of dicarboxylic acid metabolism, the aim being to identify the enzymes that determine the range of dicarboxylic acids that are produced. Such information is vital if a rational approach is to be taken to the problem of increasing dicarboxylic acid yields and manipulating the microbe to produce the dicarboxylic acids of greatest commercial value by, for example, the use of recombinant DNA technologies. The bacterium Corynebacterium sp. strain $7 \mathrm{E} 1 \mathrm{C}$ was chosen since, of a range of bacteria tested, it produced the most dicarboxylic acids (Broadway, 1990). Furthermore, this is one of the few bacteria in which dicarboxylic acid production has been investigated in any detail (Kester \& Foster, 1963; Bacchin et al., 1974; Du Pont 1973, 1974). A bacterium, rather than a yeast, was selected since the lack of subcellular compartmentalization is likely to provide the simpler experimental system.

\section{Methods}

Growth of the bacterium. Corynebacterium sp. strain 7E1C (ATCC 19067) was grown for $24 \mathrm{~h}$ on nutrient broth and then transferred to Jay's/succinate medium in a vortex-stirred bottle as described earlier (Broadway et al., 1992). Cells were harvested at the mid-exponential phase of growth. Cell-free extracts were prepared as described previously (Broadway et al., 1992). A mutant of this organism, Corynebacterium ATCC 21747, which produces increased amounts of dicarboxylic acids (Du Pont, 1973, 1974) was also examined.

\section{Enzyme assays}

$\beta$-Oxidation. $\beta$-Oxidation was measured in 'linked' and 'direct' assays as described previously (Broadway et al., 1992).

Alcohol dehydrogenase. Activity was assayed by following NAD(P) ${ }^{+}$ reduction fluorimetrically, essentially as described by Dalziel (1962). The standard assay contained, in $4 \mathrm{ml}: 3 \cdot 1 \mathrm{mmol} \mathrm{KH}_{2} \mathrm{PO}_{4} / \mathrm{K}_{2} \mathrm{HPO}_{4}$ buffer, $\mathrm{pH} 8 \cdot 0$, or $0.2 \mathrm{mmol}$ glycine $/ \mathrm{NaOH}$ buffer, $\mathrm{pH} 10 \cdot 0$, containing $3.1 \mathrm{mmol} \mathrm{Na}_{2} \mathrm{SO}_{4}, 1 \mu \mathrm{mol} \mathrm{NAD}(\mathrm{P})^{+}$and cell-free extract. The reaction was initiated by adding the substrate, either dodecanediol $(0.27 \mu \mathrm{mol})$, octan-1-ol (1.3 $\mu \mathrm{mol})$ or 12-hydroxylaurate $(1.3 \mu \mathrm{mol})$, in $20 \mu \mathrm{l}$ DMSO. When assaying for the presence of dye-linked alcohol dehydrogenase activities, $\mathrm{NAD}(\mathrm{P})^{+}$was replaced by PMS $(0.1 \mathrm{mM})$ and DCPIP $(0.05 \mathrm{~mm})$. The decrease in $A_{600}$ was followed spectrophotometrically $\left(\varepsilon_{600}=21.85 \mathrm{~mm}^{-1} \mathrm{~cm}^{-1}\right.$ at $\left.\mathrm{pH} 8.0\right)$.

Acyl-CoA synthetase. Activity was assayed by following the disappearance of free CoA-SH on incorporation into acyl-CoA esters (Webster, 1969; Vamecq et al., 1985). The assay contained, in a final volume of $190 \mu \mathrm{l}: 120 \mathrm{nmol}$ CoA-SH (trilithium salt); $750 \mathrm{nmol}$ ATP (disodium salt); $750 \mathrm{nmol} \mathrm{MgCl}_{2} .6 \mathrm{H}_{2} \mathrm{O} ; 24 \mu \mathrm{mol} \mathrm{KH}_{2} \mathrm{PO}_{4} / \mathrm{K}_{2} \mathrm{HPO}_{4}$ buffer, $\mathrm{pH} 8.0$; and $450 \mathrm{nmol}$ fatty acid substrate, introduced into the assay in $6 \mu \mathrm{l}$ DMSO. The reaction was initiated by adding the cell-free extract and terminated by adding trichloroacetic acid $(60 \mu 1 ; 15 \%$, $\mathrm{w} / \mathrm{v})$. Protein was removed by centrifugation. Supernatant $(200 \mu \mathrm{l})$ was added to $0.8 \mathrm{ml} 0.8 \mathrm{M}$-Tris $/ \mathrm{HCl}$ buffer, $\mathrm{pH} 8$, containing $250 \mathrm{nmol}$ DTNB and the $A_{412}$ was measured against an aliquot from a blank reaction from which the fatty acid substrate was omitted $\left(\varepsilon_{412}=\right.$ $13.6 \mathrm{~mm}^{-1} \mathrm{~cm}^{-1}$ for the thiol anion of DTNB).

Thioesterase. This was assayed continuously by following the increase in $A_{412}$ on reaction of released CoA-SH with DTNB. The assays contained, in $0.9 \mathrm{ml}: 130 \mu \mathrm{mol} \mathrm{KH}_{2} \mathrm{PO}_{4} / \mathrm{K}_{2} \mathrm{HPO}_{4}$ buffer, $\mathrm{pH} 8.0 ; 0.25 \mu \mathrm{mol} \mathrm{DTNB}$; and cell-free extract. The reaction was initiated by adding of $72 \mathrm{nmol}$ acyl-CoA.

'NADH oxidase'. Activity was assayed spectrophotometrically by following the decrease in $A_{340}$ on oxidation of $\mathrm{NADH}, \varepsilon_{340}=$ $6.22 \mathrm{~mm}^{-1} \mathrm{~cm}^{-1}$. Assays contained, in $0.9 \mathrm{ml}: 130 \mu \mathrm{mol} \mathrm{KH}_{2} \mathrm{PO}_{4} /$ $\mathrm{K}_{2} \mathrm{HPO}_{4}$ buffer, $\mathrm{pH} 8 \cdot 0$, and 16.5 or $33 \mathrm{nmol} \mathrm{NADH}$. The reaction was initiated by adding the cell-free extract.

Dicarboxylic acid production from different carbon sources. Bacteria were grown on nutrient broth as described above: $1 \mathrm{ml}$ was transferred to Jay's medium $(100 \mathrm{ml})$ in a $250 \mathrm{ml}$ conical flask supplemented with the appropriate carbon source $(2 \% \mathrm{w} / \mathrm{v})$. The cultures were then incubated for $120 \mathrm{~h}$ on a rotary shaker $\left(160\right.$ r.p.m.) at $30^{\circ} \mathrm{C}$.

Extraction of dicarboxylic acids. Entire cultures $(100 \mathrm{ml})$ were acidified to $\mathrm{pH} 1$ to 2 with conc. $\mathrm{H}_{2} \mathrm{SO}_{4}$. An internal standard $\left(\mathrm{DC}_{13}\right.$, $10 \mathrm{mg}$ ) was added and the culture was extracted twice with an equal volume of diethyl ether. The ether layers were combined, washed with distilled water $(0.1 \mathrm{vol}$.$) , and the ether layer was recovered and$ evaporated to dryness in a rotary evaporator at $30^{\circ} \mathrm{C}$. The residue was dried in vacuo over $\mathrm{P}_{2} \mathrm{O}_{5}$ at $55^{\circ} \mathrm{C}$. The dried residue was dissolved in methanol $(5 \mathrm{ml})$, methylated with trimethylsulphonium hydroxide (Butte, 1983) and a $1 \mu \mathrm{l}$ vol. was analysed by GLC.

Degradation of dicarboxylic acids by resting cells. Cells were grown and harvested as described above, except that sterile buffer and centrifuge tubes were used throughout. Whole-cell suspension $[5 \mathrm{ml}$, approx. $9 \mathrm{mg} \mathrm{dry} \mathrm{wt} \mathrm{ml}^{-1}$ ] was aseptically transferred to $40 \mathrm{ml}$ $100 \mathrm{~mm}-\mathrm{KH}_{2} \mathrm{PO}_{4} / \mathrm{K}_{2} \mathrm{HPO}_{4}$ buffer, $\mathrm{pH} 7 \cdot 0$, in a $100 \mathrm{ml}$ conical flask containing dicarboxylic acid $(80 \mathrm{mg})$. The flasks were incubated at $30^{\circ} \mathrm{C}$ on a rotary shaker $(160$ r.p.m.) for 18 to $120 \mathrm{~h}$. Incubations were terminated by acidification to $\mathrm{pH} 1$ to 2 with conc. $\mathrm{H}_{2} \mathrm{SO}_{4}$; a dicarboxylic acid internal standard $(10 \mathrm{mg})$ was then added and the culture medium was extracted with diethyl ether. For $\mathrm{DC}_{16}$ incubations, the internal standard was $\mathrm{DC}_{13}$. For all other incubations, the internal standard was the dicarboxylic acid two carbons longer than the test dicarboxylic acid.

GLC conditions. A Pye Unicam PU4500 Chromatograph fitted with a flame ionization detector in conjunction with a Pye Unicam CDP4 computing integrator was used with a glass column $(1.75 \mathrm{~m} \times 4 \mathrm{~mm}$ internal diameter) packed with $10 \%$ diethyleneglycol succinate on 
Celite, 100-120 mesh. The column was maintained at $200^{\circ} \mathrm{C}$ with injection and detection ports at $220^{\circ} \mathrm{C}$. The carrier gas was $\mathrm{N}_{2}$ supplied at $35 \mathrm{ml} \mathrm{min}^{-1}$

Synthesis of acyl-CoA esters. The acyl-CoA esters of $\omega$-hydroxyfatty acids and of dicarboxylic acids were synthesized and purified as described previously (Broadway et al., 1992).

\section{Results}

\section{Range of carboxylic acids produced}

Dicarboxylic acid production from $\mathrm{C}_{10}$ to $\mathrm{C}_{16}$ alkanes and fatty acid methyl esters (FAMEs) used as growth substrates for Corynebacterium 7E1C were investigated (Table 1). Dodecane gave the highest yield of a dicarboxylic acid $\left(\mathrm{DC}_{12}\right)$. Small amounts of $\mathrm{DC}_{12}$ were also produced from methyl laurate (despite the lack of growth on this as carbon source), probably due to transformation of the growth substrate by cells present in the initial inoculum. Some $\mathrm{DC}_{14}$ was produced from $\mathrm{C}_{14}$ substrates. No dicarboxylic acids were detected from either hexadecane, methyl palmitate or 16-hydroxypalmitate. Essentially the same range of dicarboxylic acids was produced by Corynebacterium sp. ATCC 21747, a mutant derived from Corynebacterium sp. strain 7E1C and which produces dicarboxylic acids in increased amounts (Du Pont 1973, 1974). Dicarboxylic acid production in the mutant was increased 3- to 4-fold as compared to Corynebacterium sp. strain 7E1C. The spectrum of dicarboxylic acids produced by Corynebacterium sp. strain 7E1C was similar to that obtained by Kester \& Foster (1963), who observed dicarboxylic acid production from $\mathrm{C}_{11}$ to $\mathrm{C}_{14}$ alkanes with dodecane and tridecane being the optimal substrates.

We have not studied fatty acid production from growth on n-alkanes in any detail, but some observations are worth noting. Analysis of total fatty acids (free and esterified) from cells grown on hexadecane showed that the major product was palmitate $(47 \%$ of the total). Tetradecanoate $(6 \%)$, dodecanoate $(18 \%)$ and decanoate $(12 \%)$ were also found. No dicarboxylic acids were produced (Table 1). After growth on dodecanol, the products were laurate $(15 \%), \mathrm{DC}_{12}(23 \%), \mathrm{DC}_{8}+\mathrm{DC}_{10}$ $(\sim 2 \%)$, palmitate $(1.4 \%)$ and a major $(\sim 40 \%)$ unidentified compound. The latter had a longer retention time on GLC than $\mathrm{DC}_{12}$ and might have been a product of $\beta$-oxidation of $\mathrm{DC}_{12}$ (perhaps 3-keto $\mathrm{DC}_{12}$ ). This unidentified material was not seen at all on growth on hexadecane.

\section{Degradation of dicarboxylic acids by resting cells}

The breakdown and metabolism of exogenous $\mathrm{DC}_{6}$ to $\mathrm{DC}_{16}$ acids by washed cells of Corynebacterium sp. strain $7 \mathrm{E} 1 \mathrm{C}$ grown on succinate was investigated (Table 2).
Degradation proceeded via a homologous series of $\mathrm{DC}_{n}$ with chain shortening by multiples of two carbon units consistent with $\beta$-oxidation. $\beta$-Oxidation is constitutive in this organism (see below) and the results are therefore relevant to $\mathrm{DC}_{n}$ production by alkane-grown cells. $\mathrm{DC}_{6}$ and $\mathrm{DC}_{8}$ were attacked rather slowly and $\mathrm{DC}_{16}$ was

Table 1. Dicarboxylic acid $(D C)$ production by Corynebacterium $7 E 1 C$ during growth on a range of carbon sources

Bacteria were grown on the appropriate carbon source for $5 \mathrm{~d}$ and then the entire culture was extracted with diethyl ether. No growth was observed on either decane or methyl decanoate and no dicarboxylic acids were detected.

\begin{tabular}{lcccc}
\hline \hline \multirow{2}{*}{$\begin{array}{l}\text { Growth } \\
\text { substrate }\end{array}$} & \multicolumn{4}{c}{ DC produced $\left(\mathrm{mg} \mathrm{ml}^{-1}\right):$} \\
\cline { 2 - 5 } & $\mathrm{DC}_{10}$ & $\mathrm{DC}_{12}$ & $\mathrm{DC}_{14}$ & $\mathrm{DC}_{16}$ \\
\hline Dodecane $\left(\mathrm{C}_{12}\right)$ & 12 & 301 & $\mathrm{ND}$ & $\mathrm{ND}$ \\
Methyl laurate $\left(\mathrm{C}_{12}\right)^{*}$ & $\mathrm{ND}$ & 24 & $\mathrm{ND}$ & $\mathrm{ND}$ \\
Tetradecane $\left(\mathrm{C}_{14}\right)$ & 10 & 6 & 17 & ND \\
Methyl myristate $\left(\mathrm{C}_{14}\right)$ & 2 & 2 & 45 & ND \\
Hexadecane $\left(\mathrm{C}_{16}\right)$ & $\mathrm{ND}$ & $\mathrm{ND}$ & $\mathrm{ND}$ & ND \\
Methyl palmitate $\left(\mathrm{C}_{16}\right)$ & $\mathrm{ND}$ & $\mathrm{ND}$ & $\mathrm{ND}$ & ND \\
16-Hydroxypalmitate $\left(\mathrm{C}_{16}\right)$ & $\mathrm{ND}$ & $\mathrm{ND}$ & $\mathrm{ND}$ & ND \\
\hline \hline
\end{tabular}

ND, Not detected.

* No growth occurred on methyl laurate; production of $\mathrm{DC}_{12}$ was probably due to transformation of the growth substrate by cells in the inoculum.

Table 2. Degradation of dicarboxylic acids $(D C)$ by washed whole cells of succinate-grown Corynebacterium $7 E 1 C$

Washed whole cells ( $5 \mathrm{ml}$, cell density as indicated) were incubated for the time shown at $30^{\circ} \mathrm{C}$ on a shaker (160 r.p.m.).

DC detected in incubation medium (mg)

\begin{tabular}{lllllll} 
Parent DC $(80 \mathrm{mg})$ & $\mathrm{DC}_{16}$ & $\mathrm{DC}_{14}$ & $\mathrm{DC}_{12}$ & $\mathrm{DC}_{10}$ & $\mathrm{DC}_{8}$ & $\mathrm{DC}_{6}$ \\
\hline
\end{tabular}

(a) $8.1 \mathrm{mg}$ dry wt $\mathrm{ml}^{-1}, 18 \mathrm{~h}$

$\begin{array}{lccrrrr}\text { DC }_{16} & 39 \cdot 6 & 0 & 1 \cdot 4 & 0 \cdot 5 & 2 \cdot 1 & 0 \cdot 2 \\ \text { DC }_{14} & & 12 \cdot 5 & 5 \cdot 1 & 6 \cdot 8 & 4 \cdot 7 & 0 \cdot 2 \\ \text { DC }_{12} & & & 12 \cdot 3 & 7 \cdot 4 & 5 \cdot 1 & 1 \cdot 2 \\ \text { DC }_{10} & & & & 0 \cdot 7 & 3 \cdot 7 & 14 \cdot 7 \\ \text { DC }_{8} & & & & & 47 \cdot 8 & 0 \\ \text { DC }_{6} & & & & & & 43 \cdot 5\end{array}$

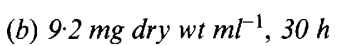

$\begin{array}{llrrrrl}\mathrm{DC}_{16} & 17 \cdot 3 & 0 & 0 & 2 \cdot 1 & 0 \cdot 9 & 0 \\ \mathrm{DC}_{14} & & 0 & 0 & 13 \cdot 6 & 32 \cdot 6 & 2 \cdot 3 \\ \mathrm{DC}_{12} & & & 14 & 20 \cdot 9 & 18 \cdot 8 & 6 \\ \mathrm{DC}_{10} & & & & 3 & 19 \cdot 2 & 7 \cdot 2 \\ \mathrm{DC}_{8} & & & & & 42 \cdot 0 & 0 \cdot 6 \\ \mathrm{DC}_{6} & & & & & & 42 \cdot 8\end{array}$

(c) $9 \mathrm{mg} d r y w t \mathrm{ml}^{-1}, 120 \mathrm{~h}$

$\begin{array}{lllllrl}\mathrm{DC}_{16} & 1 & 0 & 0 & 0 & 0 & 0 \\ \mathrm{DC}_{14} & & 0 & 0 & 0 & 0 & 0 \\ \mathrm{DC}_{12} & & & 0 & 0 & 0 \cdot 6 & 0 \cdot 8 \\ \mathrm{DC}_{10} & & & & 0 & 0 \cdot 7 & 3 \cdot 3 \\ \mathrm{DC}_{8} & & & & & 14 \cdot 9 & 44 \cdot 9\end{array}$


Table 3. $\beta$-Oxidation of monocarboxylic, $\omega$ hydroxymonocarboxylic and dicarboxylic acids by a crude cell-free extract of succinate-grown Corynebacterium $7 E 1 C$

Activity was measured as $\mathrm{NAD}^{+}$reduction in the linked assay system of Broadway et al. (1992) in potassium phosphate buffer (130 mM, pH 8.0).

\begin{tabular}{lc}
\hline \hline Substrate & $\begin{array}{c}\beta \text {-Oxidation activity } \\
\text { [nmol min }\end{array}{\left.\text { mg protein })^{-1}\right]}^{-1}$ \\
\hline Palmitate $\left(\mathrm{C}_{16}\right)$ & $38 \cdot 9$ \\
Myristate $\left(\mathrm{C}_{14}\right)$ & $30 \cdot 9$ \\
Laurate $\left(\mathrm{C}_{12}\right)$ & $28 \cdot 9$ \\
Decanoate $\left(\mathrm{C}_{10}\right)$ & $8 \cdot 3$ \\
& \\
CC $_{16}$ & $<1 \cdot 0$ \\
DC $_{14}$ & $2 \cdot 9$ \\
CC $_{12}$ & $1 \cdot 9$ \\
DC $_{10}$ & $1 \cdot 1$ \\
16-Hydroxypalmitate $\left(\mathrm{C}_{16}\right)$ & $45 \cdot 0$ \\
12-Hydroxylaurate $\left(\mathrm{C}_{12}\right)$ & $8 \cdot 4$ \\
\hline \hline
\end{tabular}

degraded to a lesser extent than $\mathrm{DC}_{10}, \mathrm{DC}_{12}$ or $\mathrm{DC}_{14}$. However $\mathrm{DC}_{16}$, unlike the other compounds used, formed a precipitate in the incubation mixture thereby decreasing its availability to the cells.

\section{$\beta$-Oxidation by cell-free extracts}

Two assays were used to follow $\beta$-oxidation. One was a linked assay in which the acyl-CoAs were generated in situ by synthetases present in the crude extracts. The other was a direct method and used chemically synthesized acyl-CoAs. The linked assay could be used only with extracts from succinate-grown cells, whereas the direct assay could be used with extracts from cells grown on various carbon sources (Broadway et al., 1992). For both assays, activity was measured by either $\mathrm{NAD}^{+}$ reduction or acetyl-CoA formation. In direct assays, the rates of acetyl-CoA formation and $\mathrm{NAD}^{+}$reduction were in the ratio of approximately $1: 1$, with lauroyl-CoA, 12-hydroxylauroyl-CoA and 16-hydroxypalmitoyl-CoA as substrates. This is as expected for $\beta$-oxidation and showed that the alcohol dehydrogenase activity that was present in cell extracts did not interfere significantly with assays of $\beta$-oxidation of hydroxy fatty acids monitored by $\mathrm{NAD}^{+}$reduction.

$\beta$-Oxidation activity in Corynebacterium sp. strain $7 \mathrm{E} 1 \mathrm{C}$ was constitutive, being expressed at similar specific activities in cells grown on glucose, succinate, 1,12dodecanediol, hexadecanol or methyl palmitate. Using myristoyl-CoA in direct assays, the specific activities were $41 \pm 6 \mathrm{nmol} \mathrm{min}^{-1}$ (mg protein) $)^{-1}$ with the carbon sources indicated (Broadway, 1990). In Escherichia coli, by contrast, the $\beta$-oxidation system is induced by growth

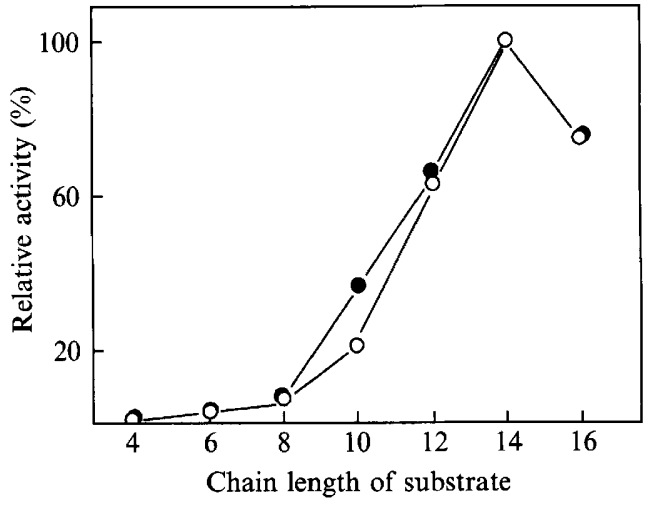

Fig. 1. Substrate specificity of $\beta$-oxidation in extracts of hexadecanolgrown and succinate-grown Corynebacterium 7E1C. Activities were measured in direct assays in potassium phosphate buffer, $\mathrm{pH} 8.0$, as described in the text. $O$, Succinate-grown cells; $100 \%=60 \mathrm{nmol}$ $\min ^{-1}(\mathrm{mg} \text { protein })^{-1}$. Hexadecanol-grown cells; $100 \%=52 \mathrm{nmol}$ $\min ^{-1}(\mathrm{mg} \text { protein })^{-1}$. $[100 \%$ refers to the activity observed with myristoyl-SCoA $\left(\mathrm{C}_{14}\right)$.]

Table 4. $\beta$-Oxidation of monocarboxyl-, $\omega$ hydroxymonocarboxyl-and dicarboxyl-CoA esters by cell-free extracts of Corynebacterium 7E1C grown on a range of carbon sources

Assays were done in potassium phosphate buffer (130 mM, pH 8.0) using the direct assay. ND, Not done.

\begin{tabular}{|c|c|c|c|}
\hline \multirow{2}{*}{$\begin{array}{l}\text { Assay substrate* } \\
(80 \mu \mathrm{M})\end{array}$} & \multicolumn{3}{|c|}{$\begin{array}{c}\text { Specific activity }\left[\mathrm{nmol} \min ^{-1}(\mathrm{mg} \text { protein })^{-1}\right] \\
\text { after growth on: }\end{array}$} \\
\hline & Succinate & Dodecanediol & Hexadecanol \\
\hline $\mathrm{C}_{16}-\mathrm{SCoA}$ & $27 \cdot 7$ & $35 \cdot 4$ & $29 \cdot 4$ \\
\hline $16 \mathrm{HO} \mathrm{C}_{16}-\mathrm{SCoA}$ & $44 \cdot 4$ & $55 \cdot 6$ & $46 \cdot 5$ \\
\hline $\mathrm{DC}_{16}-\mathrm{SCoA}_{1}$ & $10 \cdot 2$ & $5 \cdot 9$ & $7 \cdot 1$ \\
\hline $\mathrm{DC}_{16}-\mathrm{SCoA}_{2}$ & ND & ND & $1 \cdot 5$ \\
\hline $\mathrm{C}_{12}-\mathrm{SCoA}$ & $38 \cdot 6$ & $29 \cdot 5$ & $22 \cdot 3$ \\
\hline $12 \mathrm{HOC} \mathrm{C}_{12}-\mathrm{SCoA}$ & $5 \cdot 2$ & $3 \cdot 8$ & $4 \cdot 0$ \\
\hline $\mathrm{DC}_{12}-\mathrm{SCoA}_{1}$ & $3 \cdot 2$ & $1 \cdot 5$ & $2 \cdot 3$ \\
\hline $\mathrm{DC}_{12}-\mathrm{SCoA}_{2}$ & ND & ND & 0 \\
\hline
\end{tabular}

* $\mathrm{C}_{16}-\mathrm{SCoA}$, palmitoyl-CoA; $16 \mathrm{HO} \mathrm{C}_{16}-\mathrm{SCoA}$, 16-hydroxypalmitoyl-CoA; $\mathrm{DC}_{16}-\mathrm{SCoA}_{1}$, mono $\mathrm{CoA}$ ester of hexadecanedioic acid; $\mathrm{DC}_{16}-\mathrm{SCoA}_{2}$, di CoA ester of hexadecanedioic acid; $\mathrm{C}_{12}-\mathrm{SCoA}$, lauroyl-CoA; $12 \mathrm{HO} \quad \mathrm{C}_{12}$-SCoA, 12-hydroxylauroyl-CoA; $\mathrm{DC}_{12}$ $\mathrm{SCoA}_{1}$, mono CoA ester of dodecanedioic acid; $\mathrm{DC}_{12}-\mathrm{SCoA}_{2}$, di CoA ester of dodecanedioic acid.

on fatty acids (Klein et al., 1971; Overath et al., 1967, 1969; Weeks et al., 1969) and is subject to catabolite repression by glucose (Weeks et al., 1969).

The $\beta$-oxidation system of Corynebacterium sp. strain 7E1C displayed a marked preference for long-chain monocarboxylic acids (Fig. 1). Dicarboxylic acids, $\left(\mathrm{DC}_{10}\right.$, $\mathrm{DC}_{12}, \mathrm{DC}_{14}$ and $\mathrm{DC}_{16}$ ) were relatively very poor substrates in both the linked assay (free fatty acids as substrates; Table 3) and in the direct assay (acyl-CoA esters as substrates; Table 4). For $\omega$-hydroxycarboxylic acids as substrates, a dramatic change was observed on 
Table 5. Activities present in crude cell-free extracts of hexadecanol-grown Corynebacterium $7 E 1 C$ which interfere with the measurement of $\beta$-oxidation

All activities assayed in potassium phosphate buffer $(130 \mathrm{~mm}, \mathrm{pH} 8.0)$.

\begin{tabular}{|c|c|c|}
\hline Enzyme & Substrate & $\begin{array}{c}\text { Specific activity } \\
{\left[\mathrm{nmol} \min ^{-1}(\text { mg protein })^{-1}\right]}\end{array}$ \\
\hline$\beta$-Oxidation* & $\begin{array}{l}\text { Lauroyl-CoA }(80 \mu \mathrm{M}) \\
\text { 12-Hydroxylauroyl-CoA }(80 \mu \mathrm{M}) \\
\text { 16-Hydroxypalmitoyl-CoA }(80 \mu \mathrm{M})\end{array}$ & $\begin{array}{r}37 \cdot 4 \\
4 \cdot 1 \\
31 \cdot 7\end{array}$ \\
\hline Thioesterase & $\begin{array}{l}\text { Acetyl-CoA }(80 \mu \mathrm{M}) \\
\text { Acetyl-CoA }(37 \mu \mathrm{M}) \\
\text { Lauroyl-CoA }(80 \mu \mathrm{M})\end{array}$ & $\begin{array}{r}10 \cdot 6 \\
4 \cdot 1 \\
43 \cdot 0\end{array}$ \\
\hline $\begin{array}{l}\omega \text {-Hydroxyfatty } \\
\text { acid dehydrogenase }\end{array}$ & $\begin{array}{l}\text { 12-Hydroxylaurate }(80 \mu \mathrm{M}) \\
\text { 16-Hydroxypalmitate }(80 \mu \mathrm{M})\end{array}$ & $\begin{array}{l}0 \cdot 8 \\
0\end{array}$ \\
\hline 'NADH oxidase' & $\begin{array}{l}\text { NADH }(37 \mu \mathrm{M}) \\
\text { NADH }(18.5 \mu \mathrm{M})\end{array}$ & $\begin{array}{l}17 \cdot 1 \\
14 \cdot 6\end{array}$ \\
\hline
\end{tabular}

* Measured as rate of $\mathrm{NAD}^{+}$reduction.

increasing chain-length: 12-hydroxylaurate was a poor substrate, comparable to the dicarboxylic acids, but 16hydroxypalmitate was a good one (Tables 3 and 4 ).

It is noteworthy that the cell-free extracts contain a number of activities that could possibly compromise estimates of $\beta$-oxidation activity. These are NADH oxidase, long-chain acyl-CoA thioesterase and $\omega$ hydroxy fatty acid dehydrogenase (Table 5 ). The thioesterase and NADH oxidase activities would tend to lead to an underestimation of $\beta$-oxidation activity; the thioesterase had the effect of rapidly depleting the substrate concentration so that assays were linear for only a short time (3-4 min). However, as initial rates of $\beta$-oxidation were determined and as the effects of these contaminating activities would be time-dependent, errors associated with them are probably quite small. As indicated above, the alcohol dehydrogenase activity did not affect the rates of $\beta$-oxidation with the $\omega$-hydroxy fatty acids.

\section{Acyl-CoA synthetase}

Measurements of acyl-CoA synthetase activity with laurate as substrate showed the expected cofactor requirements. On omission of fatty acid (laurate) or using boiled extract, no activity was observed. On omission of ATP, the activity fell to $13 \%$ of that seen with the complete mixture. The residual activity was probably due to carry over of ATP from the extract. ATP could not be replaced by GTP, CTP, UTP or TTP (data not shown).

Acyl-CoA synthase activity was also constitutive: both lauroyl-CoA synthetase $\left[25 \pm 5 \mathrm{nmol} \mathrm{min}^{-1}(\mathrm{mg}\right.$ protein $\left.)^{-1}\right]$ and $\mathrm{DC}_{12}-\mathrm{CoA}$ synthetase $\left[17 \pm 7 \mathrm{nmol} \mathrm{min}^{-1}\right.$ $(\mathrm{mg} \text { protein })^{-1}$ ] activities were expressed similarly after growth on either succinate, 1,12-dodecanediol, hexadecanol, hexadecane or glucose. Again, this is in marked contrast to the situation in E. coli (Overath et al., 1969; Samuel \& Ailhand, 1969; Weeks et al., 1969). It is also in contrast to the inducible dicarboxyl-CoA synthetase of Acinetobacter calcoaceticus (Modrzakowski \& Finnerty, 1989).

The acyl-CoA synthetase in crude extracts of Corynebacterium sp. strain 7E1C displayed a very wide substrate specificity (Fig. 2). An essentially identical substrate specificity was observed with extracts prepared from cells grown on succinate, 1,12-dodecanediol or hexadecanol. For any given carbon source (for growth), the rate of activation of long-chain $\left(\mathrm{C}_{10}-\mathrm{C}_{16}\right)$ dicarboxylic acids was in the range of 50 to $100 \%$ of the rate for the corresponding monocarboxylic acid. Kinetic studies under the conditions described in Fig. 2 confirmed that long-chain carboxylic, $\omega$-hydroxycarboxylic and dicarboxylic acids were good substrates. Approximate $K_{\mathrm{m}}$ values of $<100 \mu \mathrm{M}$ were obtained for decanoic, dodecanoic and tetradecanoic acids. For palmitate, the value was $150 \mu$.

\section{Alcohol dehydrogenases}

Soluble $\mathrm{NAD}^{+}$- and $\mathrm{NADP}^{+}$-dependent alcohol dehydrogenases were detected in cell extracts of Corynebacterium sp. strain 7E1C. The activities were similar after growth on a wide range of carbon sources, but $\mathrm{NADP}^{+}$-octanol dehydrogenase activity was stimulated by growth on alkyl-group-containing substrates (Broadway, 1990). No nucleotide-independent alcohol dehydrogenase was detected. The alcohol dehydrogenases are stimulated 3to 4-fold by high salt concentrations and assays were routinely performed in either potassium phosphate buffer 


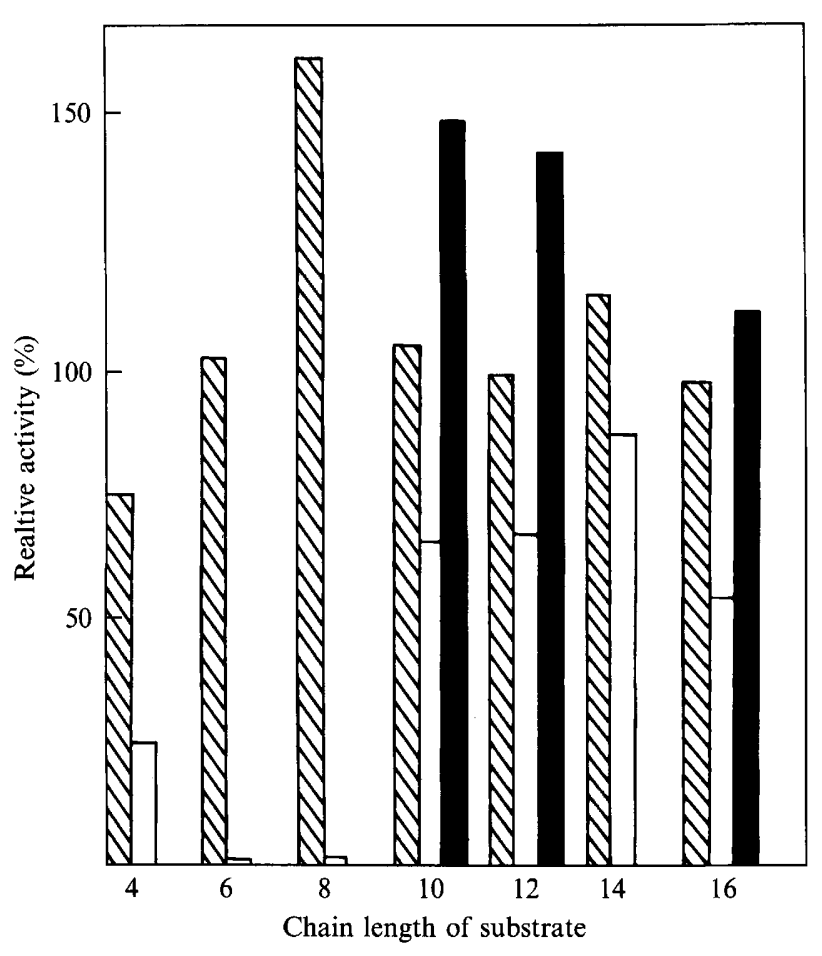

Fig. 2. Substrate specificity of acyl-CoA synthetase activity in extracts of hexadecanol-grown Corynebacterium 7E1C. Assays were performed in potassium phosphate buffer, $\mathrm{pH} 8.0$, as described in the text. $100 \%$ [refers to the activity observed with lauric acid $\left.\left(\mathrm{C}_{12}\right)\right]=20 \mathrm{nmol} \mathrm{min}{ }^{-1}$ (mg protein $)^{-1}$. $\mathbb{}$, Monocarboxylic acid; $\boldsymbol{\square}, \omega$-hydroxycarboxylic acid $\left(\mathrm{C}_{4}, \mathrm{C}_{6}, \mathrm{C}_{8}\right.$ and $\mathrm{C}_{14} \omega$-hydroxymonocarboxylic acids were not tested); $\square$, dicarboxylic acid.

Table 6. Summary of the kinetic parameters of NAD+. dependent $\omega$-hydroxyfatty acid dehydrogenase activity in a crude cell-free extract of hexadecanol-grown Corynebacterium $7 E 1 C$

Assayed in glycine buffer $(50 \mathrm{~mm}, \mathrm{pH} 10)$ containing $0.8 \mathrm{M}-$ $\mathrm{Na}_{2} \mathrm{SO}_{4}$

\begin{tabular}{|c|c|c|}
\hline Substrate & $\begin{array}{c}K_{\mathrm{m}} \\
(\mu \mathrm{M})\end{array}$ & {$\left[\begin{array}{c}V_{\max } \\
{\left[\mathrm{nmol} \min ^{-1}(\mathrm{mg} \text { protein })^{-1}\right]}\end{array}\right.$} \\
\hline 10-Hydroxydecanoate & 1520 & 50 \\
\hline 12-Hydroxylaurate & 77 & 44 \\
\hline 16-Hydroxypalmitate & 22 & 42 \\
\hline
\end{tabular}

$(0.8 \mathrm{M}, \mathrm{pH} 8.0)$ or glycine buffer $(50 \mathrm{~mm}, \mathrm{pH} 10.0)$ containing $0.8 \mathrm{M}-\mathrm{Na}_{2} \mathrm{SO}_{4}$. Substrate specificity studies showed that with both buffers the optimal substrate for $\mathrm{NAD}^{+}$- and $\mathrm{NADP}^{+}$-linked alcohol dehydrogenase was octanol, whilst 1,12-dodecanediol was the optimum $\alpha, \omega$ diol. Importantly, 1,16-hexadecanediol was a poor substrate. It was difficult to determine the specificity of the enzyme towards $\omega$-hydroxy acids in the potassium phosphate buffer system due to the combination of low rates, unfavourable equilibrium constant and high $K_{\mathrm{m}}$ for the $\omega$-hydroxy fatty acid. Conditions were more favourable at $\mathrm{pH} 10.0$ and the results obtained are recorded in Table 6 .

\section{Discussion}

Only a very narrow range of dicarboxylic acids was produced by Corynebacterium sp. strain 7E1C (Table 1) or its derived DC-accumulating mutant, Corynebacterium sp. ATCC 21747, after growth on alkanes or fatty acid esters. Whenever a dicarboxylic acid product was observed, the principal product had the same chainlength $\left(\mathrm{C}_{12}, \mathrm{C}_{14}\right)$ as the growth substrate. This suggests that the product arises by direct diterminal oxidation of the alkane substrate (Fig. 3), and not as a result of $\omega$ oxidation of chain-shortened fatty acids arising from $\beta$ oxidation. If the latter did occur, one might expect significant $\mathrm{DC}_{12}$ production from cells grown on hexadecane and this does not happen (Table 1). The

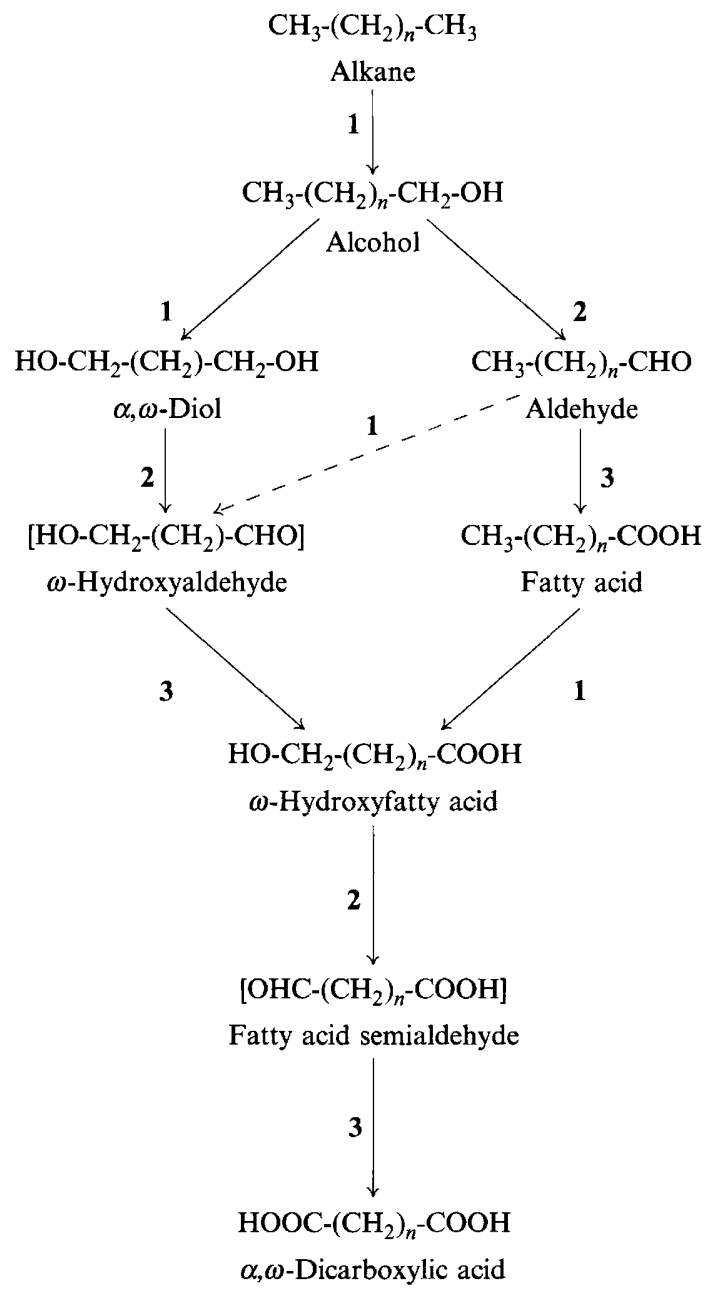

Fig. 3. Pathways of dicarboxylic acid formation from alkanes. 1, Hydroxylase; 2, alcohol dehydrogenase; 3, aldehyde dehydrogenase. [], Compound has never been isolated. 
dicarboxylic acids that are formed are not peculiarly inert as substrates for $\beta$-oxidation when they are compared to other dicarboxylic acids (Table 2); this process probably accounts for the small amounts of chain-shortened dicarboxylic acids found (Table 1). However, long-chain dicarboxylic acids are poor substrates for $\beta$-oxidation as compared to fatty acids of the same chain-length (Tables 3 and 4). This is not because of the specificities of fatty acyl-CoA synthetases (or indeed the long-chain acyl-CoA thioesterases), which do not discriminate greatly between mono- or dicarboxylic acids (or their thio esters) (Broadway, 1990). It is probably due to the specificity of the long-chain fatty acyl-CoA dehydrogenase, which is the first enzyme of the $\beta$-oxidation sequence. This enzyme appears to be ratelimiting for oxidation of both mono- and dicarboxylic acids alike (Broadway et al., 1992).

If fatty acids and dicarboxylic acids arise by terminal oxidation of alkanes and fatty acids, as shown in Fig. 3, the relative amounts formed will clearly depend on the specificities of the hydroxylase and alcohol and aldehyde dehydrogenase enzymes. If the specificities are such that a greater proportion of dodecane is converted to $\mathrm{DC}_{12}$ than hexadecane is to $\mathrm{DC}_{16}$ then, because of the slow $\beta$ oxidation of the dicarboxylic acids, $\mathrm{DC}_{12}$ would be more likely to accumulate. We have not made any studies of the hydroxylase or aldehyde dehydrogenase and the characterization of alcohol dehydrogenase and $\beta$ oxidation is only partial. However, the work suggests that if $\omega$-hydroxy fatty acids are significant metabolites in dicarboxylic acid formation and, as shown in Fig. 3 they are thought to be obligatory intermediates, then the kinetic characteristics of alcohol dehydrogenase and $\beta$ oxidation (Tables 3, 4 and 6) would favour dicarboxylic acid formation from 12-hydroxylaurate and $\beta$-oxidation for 16-hydroxypalmitate. The degree of discrimination achieved would clearly depend on the precise conditions obtaining in the cells. However, the observation that no $\mathrm{DC}_{16}$ could be detected in cultures of cells grown on 16hydroxypalmitate (here the problem of $\omega$-hydroxylase specificity is circumvented) demonstrates that, under these conditions at least, $\beta$-oxidation of 16 -hydroxypalmitate is favoured over $\omega$-oxidation to $\mathrm{DC}_{16}$. It is important to emphasize that for there to be no accumulation of $\mathrm{DC}_{16}$ it is not necessary for there to be no conversion of 16-hydroxypalmitate to $\mathrm{DC}_{16}$. As long as the rate of $\mathrm{DC}_{16}$ production and degradation are balanced, there will be no accumulation. Although the rate of $\beta$-oxidation of $\mathrm{DC}_{16}$ is low it is still significant.

The suggestions presented above illustrate the arguments about the specificities of the enzymes in Fig. 3, but it is likely that the hydroxylase as the rate-limiting step in Fig. 3 is the decisive step in determining the relative rates of mono- and dicarboxylic acid production from alkane or fatty acid. More work here is clearly needed. Also, whilst the specificities of the enzymes in Fig. 3 are important, other factors may also contribute. The cells used here are orange-red in colour and it was quite evident that the bacteria grew less well as the chainlength of the substrate was reduced to $\mathrm{C}_{12}$ and below. In fact with methyl laurate, there was some conversion of substrate to $\mathrm{DC}_{12}$ but no obvious growth (Table 1). With less vigorous growth, the decreased demand for energy would lead to lower rates of $\beta$-oxidation of fatty acids. These, being used less rapidly, are more likely to undergo terminal hydroxylation and would be more likely to be converted into dicarboxylic acids.

This work was supported by the European Community Biotechnology Action Programme (Grant no. 02100). We wish to thank Dr F. Meussdoerffer and Dr M. Bahn of Henkel KGaA, Düsseldorf, for their interest and helpful discussions.

\section{References}

Bacchin, P., Rober tiello, A. \& Viglia, A. (1974). Identification of ndecane oxidation products in Corynebacterium cultures by combined gas chromatography-mass spectrometry. Applied Microbiology 28, 737-741.

Blasig, R., Schunk, W. H., Jockisch, W., Franke, P. \& Muller, H. G. (1984). Degradation of long-chain n-alkanes by the yeast Lodderomyces elongisporus. I. Products of alkane oxidation in whole cells. Applied Microbiology and Biotechnology 19, 241-246.

Blasig, R., Mauersberger, S., Riege, P., Schunk, W. H., Jockisch, W., Franke, P. \& Muller, H. G. (1988). Degradation of long-chain n-alkanes by the yeast Candida maltosa. II. Oxidation of n-alkanes and intermediates using microsomal membrane fractions. Applied Microbiology and Biotechnology 28, 589-597.

Boulton, C. \& Ratledge, C. (1984). The physiology of hydrocarbonutilizing microorganisms. Enzyme and Fermentation Biotechnology, 9, 11-77.

BROADWAY, N. M. (1990). Enzymology of dicarboxylic acid metabolism in Corynebacterium sp. strain $7 E 1 C$. PhD thesis, University of Hull, UK.

Broadway, N. M., Dickinson, F. M. \& Ratledge, C. (1992). Acyl$\mathrm{CoA}$ intermediates of $\beta$-oxidation of mono- and dicarboxylic acids by extracts of Corynebacterium sp. strain 7E1C. Biochemical Journal 285, 117-222.

Buhler, M. \& SCHINDler, J. (1984). Aliphatic hydrocarbons. In Biotechnology, vol. 6a, pp. 329-385. Edited by H. J. Rehm \& G. Reed. Weinheim: Verlag Chemie

BUTTE, W. (1983). Rapid method for the determination of fatty acid profiles from fats and oils using trimethyl sulphonium hydroxide for transesterification. Journal of Chromatography 261, 142-145.

CASEY, J. \& MACRAE, A. (1992). Biotechnology and the oleochemical industry. INFORM 3, 203-207.

CASEY, J., DoBb, R. \& MYCOCK, G. (1990). An effective technique for enrichment and isolation of Candida cloacae mutants defective in alkane metabolism. Journal of General Microbiology 136, 1197-1202.

Chan, E. C., Kuo, J., Lin, H. P. \& Mou, D. G. (1991). Stimulation of n-alkane conversion to dicarboxylic acid by organic-solvent- and detergent-treated microbes. Applied Microbiology and Biotechnology 34, 772-777.

Dalziel, K. (1962). Kinetic studies of liver alcohol dehydrogenase. Biochemical Journal 84, 244-254.

Du Pont (1973). U.S. Patent 3773621. Process for the biological production of alpha, omega-alkanedioic acids.

Du Pont (1974). U.S. Patent 3784445. Culture medium and process for the biological production of alpha, omega-alkanedioic acids.

Furukawa, T., Matsuyoshi, T. \& Kise, S. (1986). Selection of high brassylic acid producing strains of Torulopsis candida by single-cell 
cloning and by mutants. Journal of Fermentation Technology 64, 97-101.

Hill, F. F., VenN, I. \& LuKas, K. L. (1986). Studies on the formation of long-chain dicarboxylic acids from pure n-alkanes by a mutant of Candida tropicalis. Applied Microbiology and Biotechnology 24, $168-174$.

KeSteR, A. S. \& Foster, J. W. (1963). Diterminal oxidation of long chain alkanes by bacteria. Journal of Bacteriology 85, 859-869.

Klein, K., Steinberg, R., Feithen, B. \& Overath, P. (1971). Fatty acid degradation in Escherichia coli. European Journal of Biochemistry 19, 442-451.

MODRZAKOWSKI, M. C. \& FINNERTY, W. R. (1989). Intermediary metabolism of Acinetobacter grown on dialkyl ethers. Canadian Journal of Microbiology 35, 1031-1036.

Overath, P., Raufuss, E., Stoffel, W. \& Ecker, W. (1967). The induction of the enzymes of fatty acid degradation in Escherichia coli. Biochemical and Biophysical Research Communications 29, 29-33.

Overath, P., Pauli, G. \& Schairer, H. U. (1969). Fatty acid degradation in Escherichia coli: an inducible acyl-CoA synthetase, the mapping of ald-mutations and isolation of regulatory mutants. European Journal of Biochemistry 9, 559-574.

ReHM, H. J. \& ReIFF, T. (1981). Mechanisms and occurrence of microbial oxidation of long-chain alkanes. Advances in Biochemical Engineering 19, 175-215.

Samuel, D. \& Ailhaud, G. (1969). Comparative aspects of fatty acid activation in Escherichia coli and Clostridium butyricum. FEBS Letters 2, 213-216.

SHIIO, J. \& UCHIO, R. (1971). Microbial production of long-chain dicarboxylic acids from n-alkanes. Agricultural and Biological Chemistry 35, 2033-2042.

UCHIO, R. \& SHIIO, J. (1972a). Microbial production of long-chain dicarboxylic acids from n-alkanes. Agricultural and Biological Chemistry 36, 426-433.

UCHIO, R. \& SHIO, J. (1972b). Production of dicarboxylic acids by
Candida cloacae mutant unable to assimilate n-alkane. Agricultural and Biological Chemistry 36, 1169-1175.

UCHIO, R. \& SHIIO, J. (1972c). Tetradecane-1,14-dicarboxylic acid production from hexadecane by Candida cloacae. Agricultural and Biological Chemistry 36, 1389-1397.

VAMECQ, J., De Hoffmann, E. \& VAN Hoof, F. (1985). The microsomal dicarboxyl-CoA synthetase. Biochemical Journal 230, 683-693.

WeBster, L. (1969). Acetyl-CoA synthetase. Methods in Enzymology 13, 375-381.

WeEks, E., Shapiro, M., Burns, R. O. \& WaKIL, S. J. (1969). Control of fatty acid metabolism: induction of the enzymes of fatty acid oxidation in Escherichia coli. Journal of Bacteriology 97, 827-836.

YI, Z. H. \& REHM, H. J. (1982a). Metabolic formation of dodecanedioic acid from n-dodecane by a mutant of Candida tropicalis. European Journal of Applied Microbiology and Biotechnology 14, 254-258.

YI, Z. H. \& ReHM, H. J. (1982b). Degradation pathways from ntridecane to $\alpha, \omega$-tridecanedioic acid in a mutant of Candida tropicalis. European Journal of Applied Microbiology and Biotechnology 15, 144-146.

YI, Z. H. \& REHM, H. J. (1982c). A new metabolic pathway from ndodecane to $\alpha, \omega$-dodecanedioic acid in a mutant of Candida tropicalis. European Journal of Applied Microbiology and Biotechnology 15, 175-179.

YI, Z. H. \& REHM, H. J. (1988a). Formation and degradation of $\Delta^{9}-$ 1,18-octadecanedioic acid from oleic acid by Candida tropicalis. Applied Microbiology and Biotechnology 28, 520-526.

YI, Z. H. \& REHM, H. J. $(1988 b)$. Bioconversion of elaidic acid to $\Delta^{9}$ trans-1,18-octadecenedioic acid by Candida tropicalis. Applied Microbiology and Biotechnology 29, 305-309.

YuANTONG, C. \& XIUZHEN, H. (1988). Studies on producing hexadecane dicarboxylic acid by fermentation. Chinese Journal of Biotechnology 4, 145-148.

ZHIHUA, Y. \& XIUZHEN, H. (1986). Formation and characterization of long-chain diacyl-CoA synthetase from Candida tropicalis. Acta Microbiologica Sinica 26, 333-340. 